\section{UK government refuses to budge after Lords' attack on space policy}

London

THE British government is often criticized for its attitude to space research, but last week it was the subject of a particularly scathing attack from a House of Lords committee. The Select Committee on Science and Technology said government policy on space research lacks inspiration and enthusiasm and that the British National Space Centre (BNSC) is ineffective. Responding to the attack, Lord Young, the Secretary for Trade and Industry, said that the committee's approach looks backward. He said that in asking for guidance and inspiration, the committee really wants greater public expenditure and a return to the days when government ministers tried to pick winners. He strongly disagreed that the BNSC is ineffective.

The criticisms followed the government's reply to the committee's report on national space policy, published in 1987. The reply was published last week. In it, the government ignored most of the Lords' criticisms, stressing that space projects would not be increased beyond the current level of $£ 130$ million a year. The Lords called for an increase to $£ 200 \mathrm{mil}$ lion. But in his reply last week, Lord Young said that because space projects are long-term and "notoriously expensive", the government would be selective as regards the fields of activity it entered and would involve the private sector in selecting and developing future projects.

\section{Salk president retires Berkeley}

FreDERIC de Hoffmann, president of the Salk Institute of Biological Studies in San Diego, announced his retirement last week, shortly after discovering he had been infected with the AIDS virus during a blood transfusion in 1984.

De Hoffmann, a physicist who was formerly president of Gulf General Atomic, became president of the Salk Institute in 1970. Known as a talented fund-raiser, he is credited not only with saving the institute from financial ruin, but with bringing in programmes in molecular biology and neuroscience, and engineering the institute's evolution from the visionary think-tank of its early years to a leader in experimental biology.

Rumours of his waning effectiveness that have circulated in recent years are now understood in light of his failing health.

Salk scientist and Nobel laureate Renato Dulbecco has been appointed acting president until a successor is found.

Marcia Barinaga
The government said that a major part of its civil space programme would continue to be carried out through international collaborations, particularly with the European Space Agency. But the committee retorted that unless Britain could summon up more enthusiasm for space it could not rely on its partners to continue collaborating.

The committee also said that it was disingenuous for the government to offer support to British Aerospace and RollsRoyce to find suitable collaborators for the spaceplane HOTOL if it will provide no support itself. The costs of HOTOL and the timescale of commercial returns

\section{Washington}

A MEETING impossible to contemplate thirty years ago took place in a Washington hotel room last week between dissident 'father' of the Soviet hydrogen bomb, and Edward Teller, 80 , credited with the same distinction for the US bomb.

The twenty-minute meeting took place during a photography session for a US

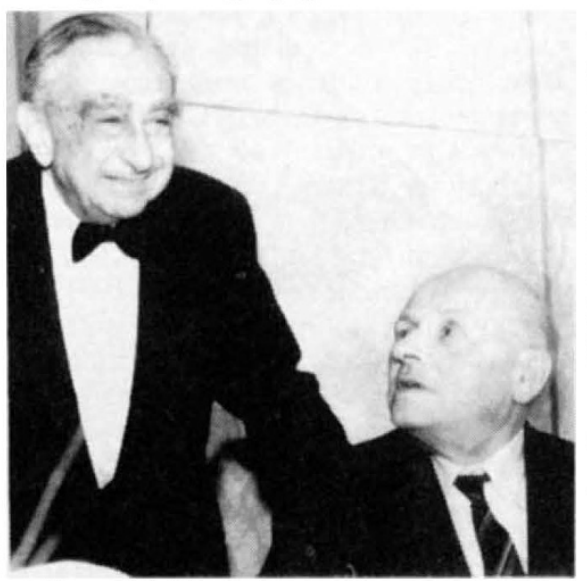
Teller and Sakharov last week.

news magazine just before a dinner sponCenter, a conservative think-tank.

While seated together under the bright lights of the photographers, they spoke of their mutual interest in the peaceful uses of nuclear power, and a shared vision of locating such reactors underground for added safety. Sakharov then steered the discussion to arms control, reiterating his belief that deployment of a space-based ballistic missile defence would have a destabilizing effect on the world balance of power. For his part, Teller, who first suggested a Strategic Defense Initiative Soviet physicist Andrei Sakharov, 67, sored by the Ethics and Public Policy are far beyond the scope of private industry and those companies are unlikely to secure foreign backing if the British government is unwilling to back the project, said the committee.

Criticizing the BNSC, which was set up to implement the country's civil space programme, the committee said it was "little more than an inter-departmental committee with a grander name" and that since the government will do nothing to strengthen BNSC, it obviously does not mind if the centre is ineffective. The committee had recommended that the BNSC be made independent with its own resources, that industrial partners be brought into it and that the directorgeneral come from industry. But the government's response indicates that there will be no change.

Christine McGourty

\title{
Sakharov and Teller meet at last in Washington
}

(SDI) to his friend President Ronald Reagan, emphasized that the technology of defence had not yet been given a sufficient trial, and that to abandon its promise would be a mistake.

Later, as Sakharov spoke at the dinner in Teller's honour, he noted how their lives had run along parallel tracks. Both men, he said, had been caught in a nationalistic fervour that made the development of a hydrogen bomb seem crucial. But now, Sakharov said, "I think that the work was a terrible tragedy". Before an audience enamoured of the promise of the SDI, Sakharov warned that "the world has entered a new era, and I am convinced that a new approach is necessary".

Teller, speaking after Sakharov had left for another engagement, agreed that their lives had moved along parallel lines. "Parallel, but of course different." Teller, a Hungarian Jew, was studying in Germany when the Nazis came to power. He moved to the United States in 1935 at the invitation of Russian expatriate George Gamow, then at George Washington University in Washington, DC.

Teller called the advances in technology the greatest hope for mankind, and noted that whereas he had been able to work in a laboratory and monitor the progress of the technology he helped to develop, his Soviet counterpart was forbidden access to sensitive information.

Neither man wavered in his commitment to principles that have guided their actions in recent years. But for one moment, as they sat and talked together, science and politics was put aside. "How is your heart", asked Teller of Sakharov who had seen a cardiologist in Boston. "It's OK", he replied, and they went down to dinner.

Joseph Palca 